\title{
UNIVERSITY EDUCATION IN NEW ZEALAND
}

$\mathrm{T}$ HE report of the Parry Committee on the New Zoaland Universities* follows in many respects that of its predocessor, the Murray Report on the Australian Universities (see Nature, 181, 300 ; 1957). It does, however, right through its various sections, emphassize again and again the present more parlous condition of the New Zealand Universities. This condition has been "engendered by the alarming rate at which staff has been lcaving, the inability to recruit new staff of adequate calibre because of low salary rates, the inadequacy of buildings and equipment, and the poor teaching conditions that, in large measure, stem from the high proportion of part-time students."

Tho Committee stresses that to fulfil their part "the Universities must play a much greater role in the New Zealand community, and must be much better suppor'ed financially than they have boen in the past". One major difficulty has been that the Now Zealand Universities have not beon "widely regarded as having a primary responsibility for original investigation and research". If the roport succeeds in changing this attitude within the country, it will have achieved a major success, and, provided the time, money and facilities bocome available, the staff should then be able "to think about the future of their society in relation to its past, to compare and rolate the contributions of other cultures to those of their own, to investigate the nature of the physical world and to keep abreast of the investigations of others".

The report directs attention to the serious shortage of university graduates in New Zealand to meet the demands of a number of professions, of many sections of industry, commerce, education and of the public services. In particular, it concludes that a substantial increase in the number of science and engineering graduates will be required for many years to come. An analysis of figures given in the report shows that in 1962 there will be about 1,300 students graduating with bachelor's degrees, and that 2,440 will be wanted in post-primary teaching, agriculture, the Civil Service and universities alone, so that "all the evidence points to an acute shortage of tho university-educated persons needed for the country's educational services and economic development". As the report points out, it is going to be essential in the future for the universities and potential employers to give more attention than they have in the past to assessing the probable future demands for people with university education and then preparing plans to meet them.

One reason for this acute shortage may be the high rate of failure among the students. There are those who believe that the entrance standards are too low and that accrediting should be replaced by examination; these people will be disappointed that there is no rocommendation to change from accrediting to examination, even when an increase has taken place in the staff of the universities.

One recommendation, which will certainly be hotly debated, is that more of the better students from

* Report of the Committee on New Zealand Universities. (Government Printer, Wellington, 1960.) 4s. $6 d$. selected schools should be allowed to commence their university studies at the second-year level. This is already permitted in Greek and mathematics, but if it is extended it will be very difficult to eliminate later. It would surely be better, if the Government accepts the Committee's recommendations for increased staffing, to introduce pass and honours degrees. The University of Canterbury already has this system in the Science Faculty, and the Science Faculties of Victoria and Otago have just introduced it. Much could also be done by raising the standards in secondary schools, though this is naturally associated with the supply of graduates for the teaching profession. The Committee further considers that more could be done to reduce the rate of failure by providing extra assistance to students in coping with the transition from school to university.

The report refers to the fact that at presont about 32 per cent of those passing university entrance examinations do not offer mathematics or a language, and that only 9 per cent offer both. Despite the importance of mathematics for a range of disciplines, more than 55 per cent of those passing entrance examinations do not offer the subject. This indicates that some changes, at least, are required in entrance requirements.

The Committee is adamant that the proportion (46 per cont) of part-time situdents (mostly in arts, law and commerce) is far too high, and that their rate of first-year failure of 60 per cent is also too high. It believes that the value of full-time study has not yet been sufficiently appreciated by students, parents, employers and the Government. It rightly recommends the transition to full-time study for as many students as possible, though this will automatically involve extra expenditure on bursaries and halls of residence.

The recommendations of the Committee on scholar. ships and bursaries are far-reaching. Many of the awards are at present too low and must be increased. Some of the awards, such as the bonded bursaries for teachers, are out of all proportion to other awards and the demands of the situation. Students who accept such bursaries commonly make a decision on their future vocation far too early in their university careers, and the recommendation to abolish the bonded bursaries should be welcomed by staff and students alike. Other important financial recommendations will enable more students to proceed to the degrees of master and doctor. For too long now students have been leaving New Zealand to study overseas, even though some departments are increasingly able to offer first-class postgraduate instruction. If the recommendations on staffing and research finance are met by the Government, there is no reason why New Zealand postgraduate training in all departments should not be the equal of any university in the Commonwealth.

The staffing position in the New Zealand Universities has reached an alarming condition, almost solely as a result of inadequate salaries. The Committee says that academic salaries must in future bear a relationship to those paid in Australia, since New Zealand has become an important source of 
Australian recruitment. It has recommended a new scale: professors $(£ 2,800)$, associate professors $(£ 2,250)$, senior locturers $(£ 1,750-£ 2,000)$, lecturers $(£ 1,250-£ 1,700)$, assistant lecturers $(£ 900-£ 1,100)$, and it is gratifying to know that the Government has accopted this rocommendation and implemented it as from April 1. This should stop further loss of teachers and enable the Univorsitios to recruit firstclass now staff. It will bo ossontial, however, to keep salaries under review, especially if Australian university salaries continue to rise. It is to be hoped that these incroases may also assist scientists in the Govornment service, who have also been leaving the country, to secure a rise in their salaries. The recommendations of the Committes on leave aro not so definito. This is to be regretted, since past experience has shown that, in the absence of definito rocommendations, there is likely to bo a long period of protracted negotiation before there is any improvement in the terms of leave and the arnount of travel grants. If tho Govornment is propared to accept tho recommendations for extra technicians, library and administrative staff, this should be of great material assistanco, especially to seionee departmonts, whero tochnical assistance is at present grossly inadequate. The libraries also require much more money to mako their collections of a size regardod as essential elsowhore. The rocommondation of an immediate grant of $£ 50,000$ may well prove inadequate even when associated with the long-term proposals for improvomont.

The report points out that university building in New Zealand is about five years behind schedule, and that when some of the buildings now being constructed are completed they will be over-crowded. The Committeo believes that the prosent annual exponditure of $£ 800,000$ on buildings will have to be increased to $£ 2$ million over the next ten years, and further, that more will have to be done by the Govornmont in providing halls of residence.

The encouragement and development of science and technology is vital to the well-being and oconomy of any country. Theso havo, so far, been unduly neglected or not appreciated in New Zealand, especially in industry. The Universities have their part to play here, and the Committee recommends that much more of the applied sciences should be included in degree courses. It also implies that thero is insufficient co-ordination of scientific research between the Universities and the Dopartment of Scientific and Industrial Research. The latter has located a number of important dopartmonts (for examplo, the Soil Bureau and the Institute of Nuclear Research) in placos distant from the univorsities, and there is no doubt that more co-ordination would benefit both the Universities and tho Department. Scienco in the Universities should also recoivo a long overdue stimulant if the Government accepts the Committeo's recommendation to increase the presont research grant of $£ 25,000$ to $£ 65,000$ this yoar and $£ 100,000$ in 1961. Another notable recommendation is for the establishment of a National Scientific Rosearch Council, which should ovorcome tho present disproportionate expenditure on research betweon Government research institutions and the Universities, and the present lack of co-ordination.

The rocommondations not to establish a veterinery school or a second school of medicino will certainly be unwelcome in some quarters in Now Zealand, though the rocommendation not to establish furthor teacher-training colloges away from the present universities will command genoral support.

The imponding disappoarance of the University of New Zoaland, the coming auionomy of the constituont Universities and the implementation of the rocom. mendations will require, the Committee reporis, the re-organization and enlargement of the presont University Grants Committoo undor a full-time chairman. Many, howevor, will not agree with the suggestion that only a minority of the members of the Committee should be drawn from the scademic institutions. The proposal to rotain the University Entrance Board may not commend itself to some, and the proposed constitution of five University and five Department of Education ropresentatives undor a chairman may woll stultify its operations.

It is evident from the foregoing that the Committee has unerringly indicated the present difficult conditions provailing in the Now Zealand Universities. The recommendations it has made will, in nearly every case, if accepted, bring those Universities up to the point whoro their status will be equal to that of the best universities in the Commonwealth. If the Government of Now Zealand, in conjunction with tho Univorsity Sonate, will act as promptly on the other recommondations as the Government has on the salary proposals, there should be little need for thoso concerned with higher education in New Zoaland to foar the future, and the Univorsitios should be able to play thoir full part in the further devolopment of the country, its economy and social life. It will also give new heart to those among the present staff who have labourod, often under incredibly difficult conditions, to build departments worthy of recognition throughout the world.

V. J. CHAPMAN

\title{
RADIOSTRONTIUM AND RADIOCAESIUM IN MILK DURING 1959
}

\author{
By W. ANDERSON, L. K. BURTON and J. O. CROOKALL \\ Physics Department, Institute of Cancer Research, Royal Cancer Hospital, London, S.W.3
}

$I^{\mathrm{T}}$ is clear from a number of reports ${ }^{1-3}$ that the concentration of long-lived fission products (strontium-90, cesiumn-137) in rain falling over Great Britain was substantially higher during the first half of 1959 than during any previous half-yearly period. In consequence, the rate of fall-out during this period was comparatively high, and, as shown recently ${ }^{4}$, tho levels of strontium-90 in milk sampled widely in Great Britain rose during tho period April-June 1959 to values which were generally higher (by a factor of the order of 1.5 ) than the peak-levels during 1958. It has also been noted ${ }^{5}$ that the levels of strontium-90 in human bone formed during the carly part of 1959 showed a significant increaso when 